\title{
RANCANG BANGUN SISTEM E2OV (ELECTRONIC - ELECTION OBSERVATION AND VOTING) MENGGUNAKAN SMS
}

\author{
Satrio Agung Wicaksono', Admaja Dwi Herlambang², R. Arief Setyawan³, Issa Arwani ${ }^{4}$ \\ Fakultas Ilmu Komputer, Universitas Brawijaya ${ }^{1,2,3,4}$ \\ ${ }^{1}$ satrio@ub.ac.id, ${ }^{2}$ herlambang@ub.ac.id, ${ }^{3}$ rarief@ub.ac.id@ub.ac.id, ${ }^{4}$ issa.arwani@ub.ac.id
}

(Naskah masuk: 22 Juli 2017, diterima untuk diterbitkan: 06 Februari 2018)

\begin{abstract}
Abstrak
Data valid tentang popularitas dan elektabilitas yang bersumber secara langsung dari masyarakat menjadi faktor penting dalam analisis kader partai untuk diusung menjadi calon legislatif dalam kegiatan pemilihan kepala daerah (Pilkada). Perancangan sistem E2OV (Electronic - Election Observation and Voting) menggunakan SMS (Short Message Service) akan mempermudah dalam mendapatkan data tersebut. Penelitian bertujuan untuk merancangan sistem observasi dan perolehan suara pemilihan secara elektronik berbasis SMS, melakukan transformasi data dari format SMS yang dikirim dengan struktur table dalam database, dan melakukan ujicoba dari sistem yang dirancang sehingga diperoleh data yang valid untuk proses analisa lebih lanjut. Metode penelitian yang digunakan adalah R\&D (research and development) yang terdiri dari tahap pra penelitian, identifikasi masalah, analisis, desain sistem, implementasi, dan pengujian. Hasil penenlitian menunjukkan bahwa: (1) hasil rancangan sistem E2OV terdiri dari beberapa elemen, yaitu cellular operator cloud, SMS gateway, modem, database server, web server, dan internet cloud; (2) transformasi data menghasilkan data dengan beberapa karakteristik, yaitu data yang dikirimkan oleh pengirim formatnya telah terstandar, tiap gateway memiliki kemampuan untuk menerima SMS sebanyak dua SMS per menit, dan diperkirakan dapat menerima 1000 SMS dalam waktu bersamaan; (3) hasil pengujian menunjukkan bahwa seluruh data sebanyak 1200 data dapat diselesaikan dalam waktu 6 jam dengan menggunakan enam buah modem.
\end{abstract}

Kata kunci: election, observation, SMS, voting

\section{SMS-BASED E2OV (ELECTRONIC - ELECTION OBSERVATION AND VOTING) SYSTEM DESIGN}

\begin{abstract}
Valid data on the popularity and electibility of legislative candidates sourced directly from the community becomes an important factor in the analysis of legislative election. The design of E2OV (Electronic - Election Observation and Voting) system using SMS (Short Message Service) will make it easier to get the data. The aims of the research are designing an observation system and electronically-based vote selection, transforming data from SMS format sent with table structure in database, and conducting a test of the system designed to obtain valid data for further analysis process. The research method used is $R \& D$ (research and development) which consists of pre-research stage, problem identification, analysis, system design, implementation, and testing. The results of the study show that: (1) the result of E2OV system design has several elements, namely cellular operator cloud, SMS gateway, modem, database server, web server, and internet cloud; (2) data transformation produces data with some characteristics, that is data transmitted by the format sender has been standardized, each gateway has the ability to receive SMS as much as two SMS per minute, and system is expected to receive 1000 SMS at the same time; (3) test results showed that all 1200 data can be completed within 6 hours using six modems.
\end{abstract}

Keywords: election, observation, SMS, voting

\section{PENDAHULUAN}

Pemilihan Umum (Pemilu) identik dengan kegiatan dimana para calon legislatif mencari dukungan dari pihak masyarakat. Banyak cara digunakan oleh para calon legislatif untuk mendapatkan simpati dari masyarakat. Masyarakat memiliki kebebasan untuk menggunakan hak pilihnya tanpa ada campur tangan maupun paksaan dari pihak lain. Banyak faktor yang akan menjadi 
penentu rakyat menjatuhkan pilihannya kepada calon legislatif yang diusung oleh partai politik, diantaranya popularitas dan elektabilitas. Popularitas lebih banyak berhubungan dengan dikenalnya seseorang, baik dalam arti positif ataupun negatif. Elektabilitas berarti kesediaan orang memilihnya untuk jabatan tertentu. Artinya, elektabilitas berkaitan dengan jenis jabatan yang ingin diraih. Orang yang memiliki elektabilitas tinggi adalah orang yang dikenal baik secara meluas dalam masyarakat. Publikasi dan kampanye memegang peranan penting untuk memperkenalkan calon legeslatif kepada masyarakat. Sebagai contoh, ada calon legislatif yang memiliki kinerja tinggi tetapi tidak elektabel karena tidak ada yang memperkenalkan kepada masyarakat.

Data yang valid tentang popularitas dan elektabilitas yang langsung dari masyarakat menjadi faktor yang sangat penting dalam analisis kader partai untuk diusung menjadi calon legislatif. Perancangan sistem E2OV (Electronic - Election Observation and Voting) menggunakan SMS (Short Message Service) akan mempermudah dalam mendapatkan data secara langsung dari masyarakat. Masyarakat hanya perlu mengirimkan SMS dengan format yang ditentukan ke sebuah nomor tertentu untuk melakukan polling ataupun voting. Kemudian, sistem akan secara otomatis membaca dan memasukkan data ke sebuah database. Dari database tersebut, selanjutnya dapat diolah datanya untuk proses analisa lebih lanjut.

Penggunaan perangkat bergerak (mobile) yang portable seperti handphone sangat membantu kemudahan pengiriman data. Pengiriman informasi melalui perangkat telepon genggam terdiri dari dua jenis, yakni menggunakan teknologi SMS dan menggunakan teknologi paket data (GPRS/EDGE/3G/4G). SMS merupakan teknologi pengiriman text sepanjang 160 karakter yang lahir sebagai bagian dari teknologi GSM pada tahun 1985 (Katankar \& Thakare, 2010), dan mulai diterapkan secara komersial pada tahun 1992. Pada tahun 2010 International Telecommunication Union (ITU) menerbitkan data bahwa jumlah sms dikirim secara global telah mencapai 192.192 sms/detik dan diperkirakan tahun ini telah lebih dari 200.000 sms dikirim tiap detik (ITU, 2010).

Teknologi SMS telah terbukti kehandalannya setelah lebih dari 20 tahun beroperasi. Saat ini teknologi pengiriman paket data telah mencapai generasi ke-4 (4G) dinyatakan dapat mencapai kecepatan hingga 1 Gbps. Riset pengujian kehandalan antara sistem SMS dengan Packet Data menghasilkan simpulan bahwa SMS lebih lambat namun dengan jaminan sampainya data pada tujuan, sedangkan Packet Data lebih cepat namun sering kali terjadi kegagalan transmisi (Dykimching, Lee, \& Yu, 2011). Penggunaan SMS sebagai sarana komunikasi pada pemilihan secara elektronik cukup handal untuk menjamin akurasi data. Hal ini mengingat seluruh perangkat mobile saat ini pasti dapat mengirimkan sms. Sedangkan untuk paket data belum semua BTS milik operator seluler yang mendukung teknologi tersebut, terutama pada daerah dengan kualitas penerimaan signal yang terbatas. Penelitian ini akan memanfaatkan SMS sebagai sarana komunikasi antara pemilik suara dengan server. Okediran, Omidiora, Olabiyisi, Ganiyu, \& Alo (2011) dalam risetnya mendesain sistem elektronik voting menggunakan three tier architecture: client tier, server tier dan database tier. Pada sistem tersebut digunakan SMS, jaringan internet dan VPN untuk menghubungkan antara client dan server. Pada penelitian Chowdhury \& Adnan (2006) melakukan analisis mendalam tentang keamanan SMS pada untuk pelaksanaan E-Voting. Penelitian tersebut mencoba mengkombinasikan antara arsitektur three tier dengan SMS Security dengan penambahan model otorisasi untuk memastikan bahwa data yang dikirim oleh seorang voter telah di terima oleh server. Pada penelitian ini pula didesain arsitektur redundancy untuk mencegah kegagalan sistem jika salah satu penerima SMS mengalami permasalahan.

Pengertian dari Electronic Voting (E-Voting) adalah penggunaan teknologi komputer pada pelaksanaan voting dimana data dicatat, disimpan, dan diproses dalam bentuk informasi digital . Menurut Schuler (2008) teknologi ini tentu saja mempunyai kelebihan dan kelemahan yang terdapat dari fungsi-fungsi yang ditawarkan oleh E-Voting. Kelebihannya, yaitu: (1) perhitungan suara yang lebih cepat, (2) menghemat surat/ kertas suara; (3) data pemilih dikumpulkan dalam kesatuan database; (4) efisiensi biaya hingga dua per tiga dari metode mencoblos atau mencentang; dan (5) penggunaan alat bisa digunakan berulang kali. Kekurangannya, yaitu: (1) sangat bergantung pada kualitas jaringan komputer/internet; (2) rentan terhadap penyadapan data; (3) diperlukan orang yang paham teknologi untuk menggunakannya; (4) data pemilih dapat dengan mudah dimanipulasi oleh pihak/golongan yang tidak bertanggung jawab; dan (5) perangkat keras/ lunak yang memakan biaya mahal ketika mengalami kerusakan. Penelitian Adeshina \& Ojo (2017) merumuskan beberapa faktor yang mendukung kesuksesan implementasi E-Voting, yaitu (1) memposisikan E-Voting sebagai sistem mutlak dan penting dalam sebuah kegaiatn pemilihan melalui regulasi; (2) memeratakan penggunaan E-Voting ke seluruh daerah area pemilihan tanpa terkecuali; (3) merencanakan implementasi E-Voting dan dikomunikasikan ke pihak ketiga yang menyediakan infrastruktu untuk operasioanlisasi sistem E-Voting; (4) pengembangan sistem E-Voting harus dilakukan dalam waktu yang realistis; (5) perlu ada kegiatan pelatihan kepada semua personalia yang terlibat dalam implementasi dan E-Voting.

SMS Gateway adalah sebuah gerbang yang menghubungkan antara komputer dengan client melalui SMS (Nur, 2011). SMS Gateway dapat didefinisikan sebagai sistem atau mekanisme yang memfasilitasi transisi SMS dengan mengubah pesan 
dari beberapa jenis media komunikasi untuk lalu lintas jaringan mobile, sebaliknya, memungkinkan, menerima atau mentransmisikan pesan SMS dengan atau tanpa menggunakan telepon genggam (Persada, Razif, Lin, \& Nadlifatin, 2014). Client secara tidak langsung berinteraksi dengan aplikasi/ sistem melalui SMS Gateway. Informasi terpenting yang diperlukan adalah nomor tujuan dan pesan, dan itulah yang sebenarnya diolah oleh SMS Gateway. Kebutuhan SMS Gateway tidak terlalu belebihan dan fleksibel karena bisa menggunakan Personal Computer (PC) maupun Notebook. Kebutuhan primernya adalah sebuah komputer, sebuah ponsel/ modem, kabel data (kabel berantarmuka serial yang dapat menghubungi ponsel dengan PC) atau dapat munggunakan InfraRed, dan piranti lunak sebagai SMS Gateway.

Aplikasi yang dibutuhkan dalam SMS Gateway adalah aplikasi yang bisa menjembatani dalam membaca dan mengirim SMS antara SMS device dengan komputer. Selain itu dibutuhkan aplikasi database yang digunakan untuk menyimpan data yang masuk dari pesan SMS yang sudah diolah. Gammu adalah software opensource yang baik untuk membangun SMS gateway. Gammu bersifat open source dibawah lisensi GPL. Pada penerapannya, bisa dikembangkan menjadi berbagai macam aplikasi terapan seperti untuk pooling SMS, server pengisian pulsa, dan sebagainya. Konsep dan cara kerja gammu sangat sederhana, yaitu melakukan koneksi ke handphone, membaca SMS yang ada di handphone lalu mengambilnya, dan menyimpannya ke dalam media penyimpanan di komputer baik itu berupa text file atau ke dalam database seperti MySQL ataupun PostgreSQL

\section{METODE}

Metode yang digunakan dalam sebuah penelitian sangat mempengaruhi kinerja sistem penelitian untuk dapat bekerja secara optimal. Metode yang sesuai dengan kebutuhan diharapkan dapat berjalan dengan baik, sehingga bisa mengikuti metode atau prosedur yang diberikan. Secara garis besar penelitian ini dibagi menjadi dua tahap yaitu tahap pre-research (penelitian pendauluan) dan tahap lanjutan yang bertujuan untuk memperbaiki hasil dari pre-research. Pada tahap pre-research didesain sebuah arsitektur sistem E2OV secara garis besar bagaimana proses terkirimnya SMS sampai dengan ditampilkan pada web interface yang ditunjukkan seperti pada Gambar 1.

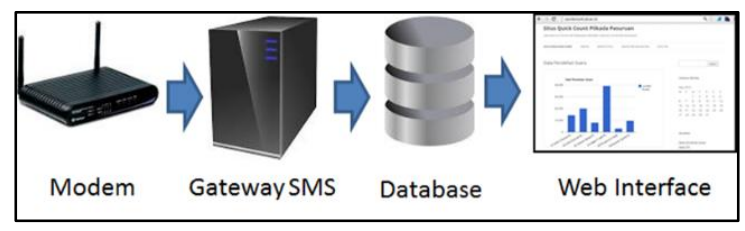

Gambar 1. Arsitektur Sistem E2OV pada Tahap preresearch (Penelitian Pendahuluan)
Pada Gambar 1, modem akan bertugas menerima pesan dari pengirim selanjutnya akan didownload oleh SMS Gateway untuk dimasukkan ke dalam database, pada database terdapat sebuah routine yang akan bertugas melakukan parsing SMS sesuai dengan format yang dikirim, desain alur proses pada database dalam melakukan parsing ditunjukkan pada Gambar 2. Setelah dilakukan parsing data yang sesuai dengan format sms pengiriman, format sms dapat dilihat pada Gambar 3. Kemudian bagian paling akhir adalah data akan disajikan pada web interfance seperti yang ditunjukkan pada Gambar 4.

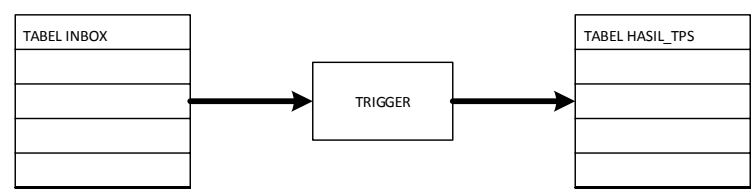

Gambar 2. Proses Parsing dalam Database

Pada Gambar 2 menunjukkan proses yang dilakukan di dalam database. Dimana SMS yang diterima oleh SMS Gateway akan masuk ke tabel INBOX, tabel INBOX adalah tabel yang sudah tersedia pada GAMMU. Setelah SMS masuk ke tabel INBOX, kemudian TRIGGER pada tabel tersebut akan bekerja melakukan parsing SMS, sehingga setiap bagian karakter SMS dapat diperoleh informasi untuk setiap data yang diwakili seperti yang ditunjukkan pada Gambar 3. Setelah SMS di-parsing sesuai dengan format yang benar maka data akan dimasukkan pada tabel HASIL_TPS, tabel inilah yang akan diakses oleh Web Interface yang selanjutnya akan menjadi bentuk tampilan seperti Gambar 4.

Format SMS yang digunakan disajikan pada Gambar 3. Contoh dari implementasi formast SMS adalah

\$\#4\#11\#03:1,124:2,565:3,056:4,006:5,124:6,236\#.

\$\#kode_kecamatan\#kode_desa\#kode_tps:calon_ ke1,jml_suara:calon_ke2,jumlah_suara:calon_ke 3,jumlah_suara:calon_ke4,jumlah_suara:calon_k e5,jumlah_suara:calon_ke6,jumlah_suara\#

Gambar 3. Format SMS

Total data yang dikirim sebanyak 496 SMS dan dengan penerimaan data yang disajikan pada Gambar 5. Pada penelitian pendahuluan diperoleh beberapa kendala, yaitu (1) Pada saat TPS (Tempat Pemungutan Suara) ditutup, maka setiap perwakilan TPS akan mengirimkan sms ke server gateway. Hal ini menyebabkan peningkatan lalulintas sms secara drastis pada server yang menyebabkan terjadinya kelambatan respon; (2) Saat SMS yang diterima melebihi kemampuan buffer pada modem, terjadi permasalahan pada gateway SMS. Aplikasi gateway 
tidak dapat merespon data yang datang. Sehingga memerlukan penanganan secara manual; (3) Seringkali terjadi kesalahan format data yang dikirim. Dari hasil analisis tersebut diperlukan perbaikan untuk meningkatkan kehandalan sistem sehingga dapat menangani sistem e-vooting maupun SMS pooling dengan skala yang lebih besar.

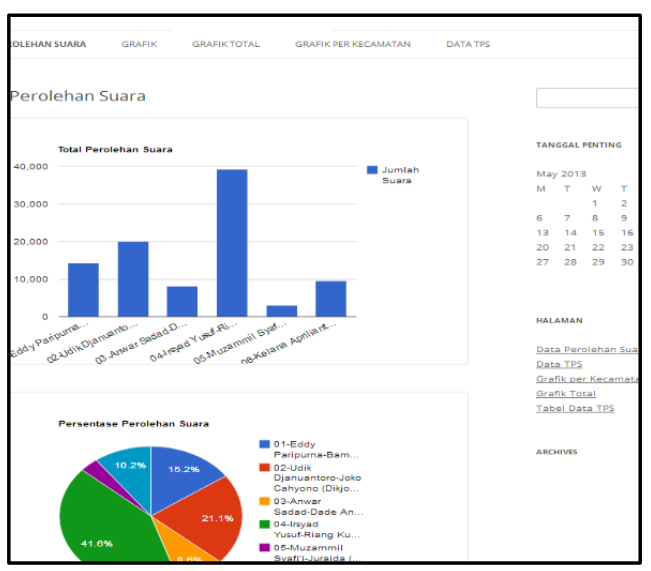

Gambar 4. Tampilan Web Quickcount



Gambar 5. Grafik Jumlah Data Diterima Berdasarkan Waktu

Dari hasi tahap pre-research selanjutnya masuk pada tahap lanjutan untuk melakukan perbaikan terhadap hasil pre-research yang diawali dengan identifikasi masalah dengan batasan yang jelas dari penelitian ini baik melalui wawancara, studi pustaka, dan observasi. Hasil dari identifikasi masalah selanjutnya dilakukan analisis pengujian kemampuan dan kecepatan proses sebuah modem mengingat saat simulasi voting ribuan data berupa dapat masuk bersamaan, sehingga diperkukan pengujian kemampuan dan kecepatan proses sebuah modem. Pengujian dilakukan dengan mengirimkan data dari beberapa handphonel modem yang mengirim data secara bersama, kemudian dicatat waktu hingga seluruh data telah tercatat dengan baik. Dengan demikian dapat dihitung jumlah responden dan banyaknya modem yang diperlukan. Pengujian kedua adalah dengan menguji kecepatan proses antara server dan database penyimpanan. Dengan demikian diharapkan data-data untuk desain sistem telah tersedia. Pada tahap ini pula di desain sistem pengamanan dengan mekanisme write one read many (WORM) sehingga setiap kali satu nomor mengirim data, maka data lain yang dikirim dari nomor tersebut tidak lagi diakui. Selain itu dibuat mekanisme pengembalian data sebagai informasi bagi pengirim bahwa data telah diterima di server. Pada tahap desain sistem dilakukan kegiatan merancang sebuah arsitektur three ttier (client, server, dan database) dengan mekanisme redundancy berdasarkan hasil penelitian pendahuluan. Redundancy modem diperlukan sebagai antisipasi jika salah satu modem mengalami overload atau terjadi permasalahan secara elektronik. Pada tahap ini pula dirancang sistem secara keseluruhan mulai dari interface pengguna, pengolahan input, dan menghasilkan output sebuah kesimpulan.

Pada tahap implementasi dilakukan kegiatan menyatukan seluruh komponen dan menyusunnya sesuai dengan desain. Arsitektur redundant three tier dibangun dan di uji konektivitas antara satu subsistem dengan sub sistem lainnya. Pada tahap pengujian dilakukan pengujian sistem baik perangkat keras maupun perangkat lunak. Pengujian dilakukan dengan menggunakan beberapa set modem dan PC yang secara terus menerus mengirimkan data ke sistem yang dibangun. Secara simultan proses validasi data oleh sistem, waktu data dikirim maupun waktu data diterima dicatat oleh server.

\section{HASIL DAN BAHASAN}

Salah satu kendala yang pernah dialami dalam penelitian pendahuluan kemampuan sistem dalam menampung ribuan SMS dalam waktu bersamaan. Hal ini menjadi referensi dalam mengembangan arsitektur SMS Gateway yang lebih solid dalam menampung data SMS. Gambar 6 menunjukkan desain redundan sistem pada SMS Gateway. Sistem yang didesain telah mempertimbangkan beberapa hal, yaitu: (1) data yang dikirimkan oleh pengirim formatnya telah terstandar, (2) tiap gateway memiliki kemampuan untuk menerima SMS sebanyak dua SMS per menit, dan (3) diperkirakan dapat menerima 1000 sms dalam waktu bersamaan.

Pada proses pengujian diuji jumlah SMS yang dapat diterima oleh satu modem. Hal ini dilakukan dengan cara mengiriman $10 \mathrm{sms}$ secara bersamaan melalui 10 perangkat seluler ke salah satu nomor modem. Berdasarkan data yang diperoleh didapatkan data yang disajikan pada Gambar 7.

Hasil pengujian tersebut diambil sebagai sampel data untuk mendesain sistem yang akan diuji pada proses QuickCount. Proses QuickCount merupakan sarana pengujian yang tepat terhadap performansi sistem SMS Gateway. Pada proses QuickCount digunakan 6 modem untuk menerima data dari 1200 TPS. Hasil dari proses pengujian pada QuickCount disajikan pada Gambar 8. Gambar 8 menunjukkan data SMS yang diterima dalam jam tertentu. Gambar 8 juga menunjukkan bahwa pada jam 14.00 jumlah SMS yang diterima mencapai 827 pesan. Sedangkan jika ditelusuri hingga 15 menit, 
diperoleh data SMS sebanyak 259 data yang diterima antara pukul $14.30-15.00$.

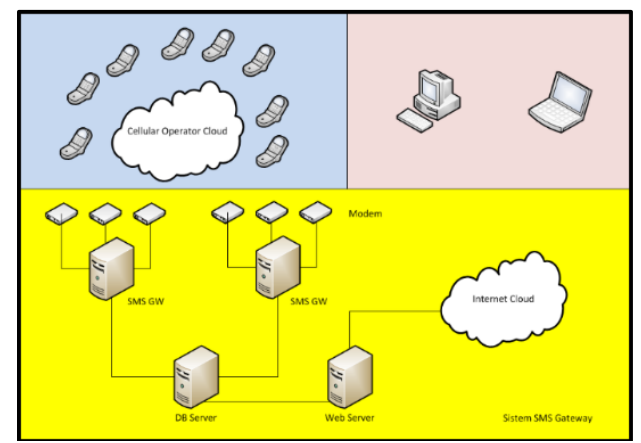

Gambar 6. Desain Sistem SMS Gateway



Gambar 7. Grafik Jumlah SMS per Menit

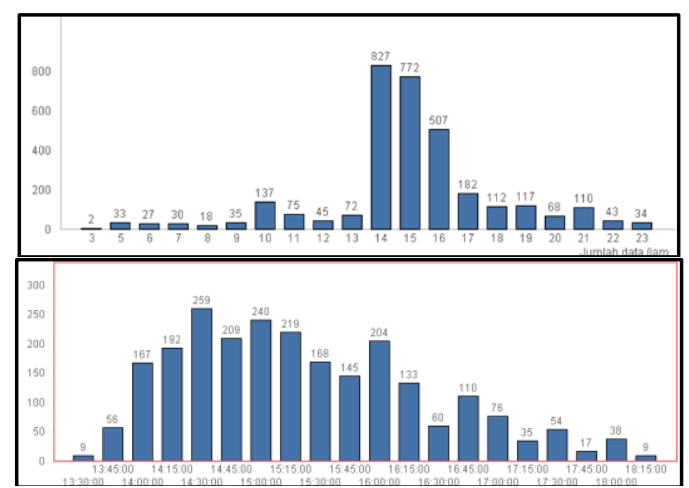

Gambar 8. Jumlah Data Setiap 15 Menit

Pada Gambar 9 menunjukkan bahwa jumlah SMS yang dikirimkan oleh 11 nomor pengirim terbanyak, yaitu sebanyak 56 SMS. Selain itu, Gambar 9 juga menunjukkan bahwa dari 6 modem yang terpasang modem 2-1 merupakan modem yang menerima data terbanyak yakni sebesar 1185 data. Dari hasil uji coba menunjukkan bahwa dengan membagi pengiriman data ke 6 modem memiliki pengaruh terhadap proses penerimaan SMS pada server SMS Gateway semakin banyak modem penerima dan membagi pengiriman secara merata akan membuat proses penerimaan sms pada server SMS Gateway akan jauh lebih cepat responya.

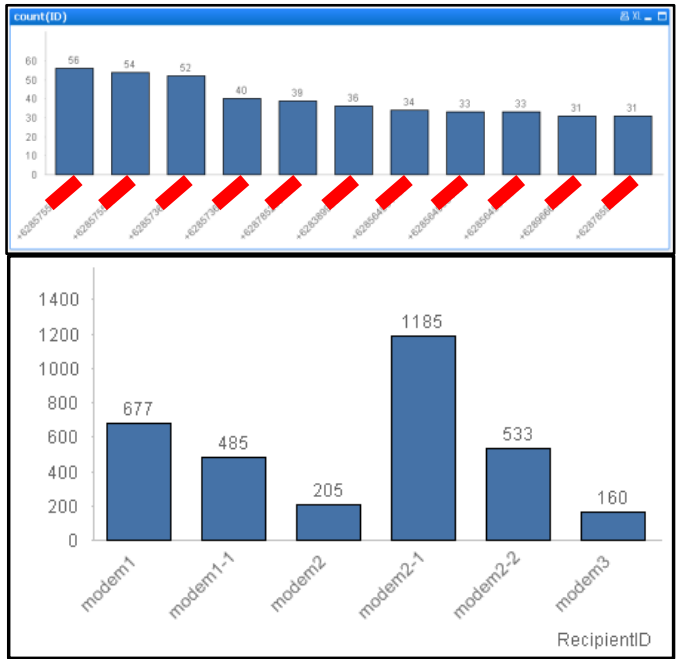

Gambar 9. Pengirim SMS Terbanyak dan Data Modem Pemenerima Data

\section{SIMPULAN}

Hasil penenlitian dapat disimpulkan bahwa: (1) hasil rancang bangun sistem E2OV terdiri dari beberapa elemen, yaitu cellular operator cloud, SMS gateway, modem, database server, web server, dan internet cloud; (2) transformasi data menghasilkan data dengan beberapa karakteristik, yaitu data yang dikirimkan oleh pengirim formatnya telah terstandar, tiap gateway memiliki kemampuan untuk menerima SMS sebanyak dua SMS per menit, dan diperkirakan dapat menerima $1000 \mathrm{sms}$ dalam waktu bersamaan; dan (3) hasil pengujian menunjukkan bahwa seluruh data sebanyak 1200 data dapat diselesaikan dalam waktu 6 jam dengan menggunakan enam buah modem. Untuk meningkatkan performansi sistem SMS diperlukan beberapa hal, yaitu: (1) diperlukan mekanisme yang dapat membagi beban antar modem; (2) penggunaan load balancing server pada web server ketika diakses banyak pengguna; dan (3) memisahkan DBMS yang diakses oleh modem dengan yang diakses oleh aplikasi web.

\section{DAFTAR PUSTAKA}

ADHESINA, S.A. \& OJO, A. 2017. Factors for EVoting Adoption - Analysis of General Elections in Nigeria. Government Information Quarterly, 34(4), 1 - 12.

CHOWDHURY, M.R., \& ADNAN, K.S. 2006. Study Of SMS Security As Part Of An Electronic Voting System. Bangladesh: BRAC University.

DYKIMCHING, A.M., LEE, J.A.A., \& YU, W.E. 2011. A Study on the Reliability of Data Transmission of an over the Top Network Protocol on SMS versus UDP/ GPRS (Fragmented). International Conference on 
6 Jurnal Teknologi Informasi dan Ilmu Komputer (JTIIK), Vol. 5, No. 1, Maret 2018, hlm. 1-6

Networked Digital Technologies. 11-13 Juli, Macau, Cina. 67-81.

ITU. 2010. The World In 2010: ICT Facts And Figures. International Telecommunication Union, [online] Tersedia di:<http://www.itu.int/net/itunews/issues/20 10/10/04.aspx> [diakses 1 Juli 2017].

KATANKAR, V.K., \& THAKARE, V.M. 2010. Short Message Service Using SMS Gateway. International Journal on Computer Science and Engineering, 2(4), 1487-1491.

NUR, I.S. 2011. Sms Online Application With Gammu. [pdf] Gunadarma University Library. Tersedia di: $<$ http://papers.gunadarma.ac.id/files/journal s/3/articles/15622/public/15622-43916-1PB.pdf> [Diakses 1 Juli 2017].

OKEDIRAN, O.O., OMIDIORA, E.O., OLABIYISI, S.O., GANIYU, R.A., \& ALO, O.O. 2011. A Framework For A Multifaceted Electronic Voting System. International Journal of Applied Science and Technology, 1(4), 135142.

PERSADA, S.F., RAZIF, M., LIN, S.C., \& NADLIFATIN, R. 2014. Toward Paperless Public Announcement on Environmental Impact Assessment (EIA) through SMS Gateway in Indonesia. Procedia Environmental Sciences, 20, 271-279.

SCHULER, I. 2008. SMS As a Tool in Election Observation (Innovations Case Narrative: National Democratic Institute). Innovations: Technology, Governance, Globalization, 3 (2), 143-157. 